\title{
RELAÇÃO INDIVÍDUO-ORGANIZAÇÃO
}

O Professor José Henrique de Faria, da Universidade Federal do Paraná, pesquisa há cerca de 25 anos temas centrais em estudos organizacionais, tais como relações de trabalho, poder, formas de controle e processos que permeiam as práticas relacionais nas organizações. As indicações bibliográficas a seguir compreendem obras significativas da perspectiva crítica sobre a relação indivíduo-organização. Apesar de não terem suas obras mencionadas, vale notar que autores como Didier Anzieu, Enrique Pichon-Riviére, Otto Kernberg e Max Pagés também trouxeram importantes reflexões sobre o tema. Os textos escolhidos procuram oferecer diferentes leituras, permitindo aos interessados percorrer o complexo caminho que o tema demanda.

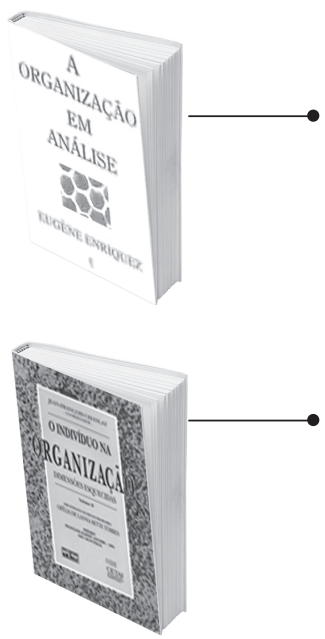

A ORGANIZAÇÃO EM ANÁLISE Eugène Enriquez. Petrópolis: Vozes, 1977. 302 p.

É um texto clássico. Enriquez, pioneiro no uso da psicanálise de fundamento freudiano para explicar fenômenos sociais e organizacionais, oferece uma concepção inovadora em comparação à tradição norte-americana de análise. O autor propõe sete diferentes instâncias de análise mítica, social-histórica, institucional, organizacional, grupal, individual e pulsional - tendo o sujeito como foco. Enriquez é uma referência no estudo dos sujeitos nas organizações e seus inúmeros trabalhos poderão ser bem melhor apreciados a partir da leitura deste estudo pioneiro.

O INDIVÍdUO NA ORGANIZAÇÃO: dimensões esquecidas Jean-François Chanlat (Coord.). São Paulo: Atlas, 1996, v. 3.208 p.

Esta coletânea tem como ponto de partida as mudanças na sociedade contemporânea. Os assuntos abordados cobrem vasta área de conhecimento, da antropologia à realidade psíquica, passando pela linguagem, por símbolos, tempo, poder, alteridade, inveja, cultura, gênero, identidade, conflitos, desejo e pulsões. A composição de assuntos tão variados, longe de ser desordenada, possui uma unidade que é exatamente a relação indivíduo-organização. Com isto, tal relação pode ser apreciada de forma interdisciplinar e, ao final, uma importante visão de conjunto é oferecida.

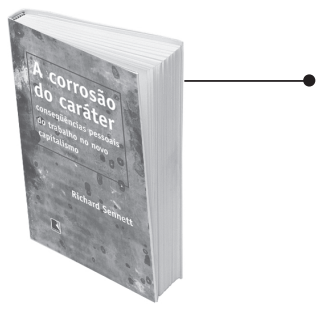

A CORROSÃO DO CARÁTER: conseqüências pessoais do trabalho no novo capitalismo Richard Sennett. Rio de Janeiro: Record, 1999. 208 p.

Nesta obra, Sennett oferece um retrato impressionante sobre a vida do indivíduo nas modernas organizações. O autor mostra que o ambiente de trabalho mais humano, proporcionado atualmente pelas empresas, em comparação àquele do início do século passado, é meramente ilusório. O novo ambiente não impede apenas que os indivíduos possam desenvolver experiências coerentes com suas vidas, mas também a formação do caráter. Lealdade, comprometimento, confiança, solidariedade e cooperação, virtudes constitutivas do caráter, estão desaparecendo no novo capitalismo.

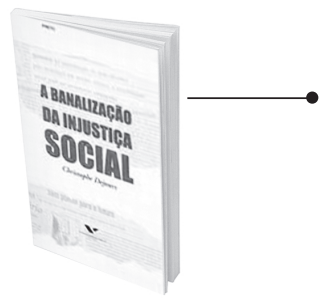

A BANALIZAÇÃo DA INJUSTIÇA SOCIAL Christophe Dejours. Rio de Janeiro: FGV, 1999. 160 p.

Christophe Dejours é autor de vasta obra dedicada ao estudo das psicopatologias do trabalho. Neste livro, o autor retoma a pergunta de Hanna Arendt: será possível que a injustiça social esteja tão banalizada que não impressiona mais o indivíduo, que não o impulsiona para a ação? Para Dejours, na guerra econômica na qual está em causa a sobrevivência das nações, utilizam-se no mundo do trabalho métodos cruéis de eliminação dos que não estão aptos para o combate pelo desenvolvimento da competitividade.

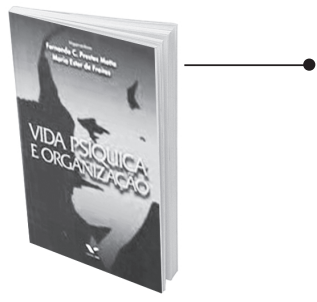

VIDA PSÍQUiCa E ORGANIZAÇÃo Fernando C. Prestes Motta e Maria Ester de Freitas (Orgs.). Rio de Janeiro: FGV, 2000. 152 p.

O livro reúne textos de pesquisadores brasileiros e franceses sobre a vida psíquica nas organizações a partir de uma perspectiva freudiana. O foco central é o sujeito, que é capaz do desejo, que luta contra angústias, receios e medos. Raramente uma organização consegue enfrentar os problemas colocados no livro, seja por receio das conseqüências, que podem ser imprevisíveis, seja pelo desconhecimento. O livro é um convite, por sua acessibilidade, para a aventura de reencontrar a dimensão humana, subjetiva, do indivíduo. 